Kastamonu Eğitim Dergisi
$\begin{aligned} & \text { Kastamonu Education Journal } \\ & \text { Ocak } 2020 \text { Cilt:28 Sayı:1 } \\ & \text { kefdergi.kastamonu.edu.tr }\end{aligned}$

\title{
Okul Öncesi Öğretmen Adaylarının Tükenmişlik ve Yabancılaşma Düzeylerinin Farklı Değişkenler Açısından İncelenmesi
}

\section{Investigating Burnout and Alienation Levels of Preschool Teacher Candidates in terms of Different Variables}

\author{
Alev ÖNDER ${ }^{1}$, Özge CENGiZ², Asude BALABAN DAĞAL ${ }^{3}$
}

Öz

Bu araştırmada Okul Öncesi Eğitimi bölümünde öğrenim görmekte olan son sınıf öğrencilerin okul tükenmişliği ve okula yabancılaşma düzeylerini incelemek amaçlanmıştır. Örneklemi Okul Öncesi Eğitimi bölümünde öğrenim görmekte olan 300 öğrenci oluşturmaktadır. Araştırmada veriler "Kişisel Bilgi Formu”, "Öğrenci Yabancılaşma Ölçeği” ve "Maslach Tükenmişlik Envanteri Öğrenci Formu” kullanılarak elde edilmiştir. Son sınıftaki okul öncesi öğretmen adayları "orta” düzeyde okul tükenmişliği ve okula yabancılaşma yaşamaktadır. Sonuçlara bakıldığında, devlet üniversitelerinde öğrenim görmekte olan öğrencilerin özel üniversitelerdekilere göre daha yüksek düzeyde duyarsızlaşma ve tükenme yaşadıkları görülmüştür. Öğrencilerin okula yabancılaşma düzeyleri üniversite türüne göre farklılık göstermemektedir. Mezun olunan lise türü değişkenine ait sonuçlar Anadolu öğretmen lisesi mezunlarının genel lise ve meslek lisesi mezunlarına göre daha fazla tükenmiş olduklarını; Anadolu lisesi mezunlarının genel lise mezunlarına göre daha fazla yabancılaşmış olduklarını göstermektedir. Ayrıca Anadolu öğretmen lisesi ve Anadolu lisesi mezunu öğrencilerin yabancılaşmanın alt boyutu olan anlamsızlık düzeyleri genel lise mezunlarına göre daha yüksek bulunmuştur. Eğitim alınan üniversite sayısına göre öğrencilerin okul tükenmişliği ve okula yabancılaşma düzeyleri farkılık göstermemiştir. Öğrencilerin yaşları ile okul tükenmişlik düzeyleri arasında istatistiksel olarak anlamlı bir ilişki bulunmamıştır. Öğrencilerin genel okula yabancılaşma düzeyleri ile yaşları arasında negatif yönlü bir ilişki bulunmuştur.

Anahtar Kelimeler: tükenmişlik, yabancılaşma, okul tükenmişliği, okula yabancılaşma, öğrenci tükenmişliği

Abstract

In this research, it was aimed to examine the levels of school burnout and alienation from school of the senior students who are studying in the Preschool Education departments. The sample consisted of 300 students who were studying in the Preschool Education departments. The data were obtained by using the "Personal Information Form", "Student Alienation Scale" and "Maslach Burnout Scale Student Form". The preschool teacher candidates in the last class experience school burnout and alienation from school at the "middle" level. When examining the results, it was seen that the students who were studying in public universities experienced a higher level of depersonalization and burnout than the students in private universities. The alienation from school levels of the students did not differ according to the type of university. The results indicated that Anatolian teacher training high school graduates were more exhausted than general high school and vocational high school graduates and Anatolian high school graduates were more alienated than general high school graduates. In addition, according to results, Anatolian teacher training high school and Anatolian high school graduates had higher levels of meaningless, which was the subdimension of alienation from school, than general high school graduates. According to the number of universities studied at, the school burnout and alienation from school levels of the students did not differ. There was no statistically significant relationship between age of students and school burnout levels. There was a negative relationship between the general level of alienation from school and age of the students.

Keywords: burnout, alienation, school burnout, alienation from school, student burnout

\footnotetext{
${ }^{1}$ Bahçeşehir University, Okul Öncesi Eğitim Bölümü, İstanbul, Türkiye, http://orcid.org/0000-0002-2736-4600

2 Marmara University, Okul Öncesi Eğitim Bölümü, İstanbul, Türkiye, http://orcid.org/0000-0003-0628-3825

${ }^{3}$ Marmara University, Okul Öncesi Eğitim Bölümü, İstanbul, Türkiye, http://orcid.org/0000-0002-9527-5335

Atıf / Citation: Önder A., Cengiz, Ö. ve Balaban Dağal, A. (2020). Okul Öncesi Öğretmen Adaylarının Tükenmişlik ve Yabancılaşma Düzeylerinin Farklı Değişkenler Açısından Incelenmesi. Kastamonu Education Journal, 28(1), 202-219. doi:10.24106/kefdergi.3508
} 


\section{Extended Abstract}

Purpose: In the field of education school burnout and school alienation problems which have significant impacts on pre-service teachers, may cause that the students develop a negative attitude towards his / her school, the education activities given to him, the profession he will perform. For this reason, it is important to carry out the research which includes the variables of school burnout and alienation from school together, to understand the possible causes of the two concepts and their relations with each other and to take necessary measures. The aim of this study was to investigate the school burnout and school from alienation levels of preschool teacher candidates in terms of various variables.

Method: This research is a descriptive study planned according to relational screening model. The population of the study consists of 494 senior students studying in preschool education in public universities and private universities in istanbul in the academic year 2017-2018. Of these students, 210 student study in state universities and 284 in private universities. In order to determine the sample of the study, the sample size calculation formula was used when the number of the population was known. Thus, the number of students participating in the research is 300 and all are girls. Of these students, 164 students study in private universities and 136 students in public universities. The students who participated in the study stated that their socioeconomic levels were at a moderate level. "Personal Information Form", "Student Alienation Scale", "Maslach Burnout Inventory Student Form" which contains independent variables, was used in the study. While the data is collected, 7 universities ( 3 states, 4 private) in İstanbul were contacted and data were collected from these universities. Independent samples t-Testi, single-factor variance analysis, Scheffe test, Pearson test were used to analyze the data.

Findings: According to the results of the research, preschool teacher candidates were experiencing school burnout and alienation from the school at a "medium" level. It was seen that the students who were studying in public universities experienced a higher level of depersonalization and burnout than the students in private universities. The alienation from school levels of the students did not differ according to the type of university. However, the meaninglessness sub-dimension was found to be higher level in the students at public universities than in the private universities. The results indicated that Anatolian teacher training high school graduates were more exhausted than general high school and vocational high school graduates and Anatolian high school graduates were more alienated than general high school graduates. In addition, Anatolian teacher training high school and Anatolian high school graduates had higher levels of meaningless, which was the sub-dimension of alienation from school, than general high school graduates. According to the number of universities studied at, the school burnout and alienation from school levels of the students did not differ. There was no statistically significant relationship between age of students and school burnout levels. The results showed that there was no significant relationship between age variable and alienation from school subscales of irregularity, isolation and meaninglessness. In addition, there was a negative relationship between the general level of alienation from school and age of the students. According to this, as age increases, alienation from school decreases.

Conclusion and Discussion: School burnout and school alienation problems of students at high levels can reach high levels in cases such as lack of necessary solutions, not caring about the subject and not providing adequate support to the students, and not doing preventive studies. According to the results of the research, students in state universities experience higher levels of school burnout. This may be due to the fact that the scores of state universities are higher than private universities in university entrance examinations. As a result, students studying at state universities have to get higher scores in these exams and have studied more. With regard to alienation from school, it is seen that the level of meaninglessness of the students in the state universities is higher. The high level of meaninglessness of students in public universities may be related to the inadequacy of social and cultural activities in these universities. While it is concluded that the Anatolian teacher training high school graduates are more burnout than the general high school and vocational high school graduates, it is determined that the Anatolian high school graduates have been alienated to higher level than the general high school graduates. This may be due to the fact that Anatolian teacher training high school graduates receive training courses during their high school period and as a result, they may become exhausted in time. The reason why the graduates of the Anatolian high school is alienated at the higher level compared to the general high school graduates may be thought to have had a more intensive education period in their high school years. As the reason of the lack of meaningful relationship between the age of the students participating in the research and burnout, depersonalization, irregularity, isolation, and meaninglessness, it can be considered that the whose ages worked with student close to each other. Because only senior students were studied in the research. The fact that the students who are older are less likely to experience alienation and burnout compared to are younger, can be explained as the development of the ability of combating with problems of individuals as take age. 


\section{Giriş}

Bireylerin yaptıkları işlerde veya yaşadıkları ilişkilerde zorluklar yaşamaları ve buna ek olarak bir şeylerin yolunda gitmediği yönündeki düşüncelerinin artması beraberinde çă̆ımızın önemli bir sosyal problemini getirmektedir. Tükenmişlik (Burnout) olarak adlandırılan bu mesleki tehlike Amerika'da 1970'li yıllarda daha çok hizmet sektöründe çalışan insanlarda saptanmaya başlanmıştır (Okutan, 2010).

Maslach tükenmişlik kavramını "işi nedeniyle oldukça fazla duygusal yıpranmalar yaşayan ve yoğun bir şekilde çevresindeki insanlarla birlikte çalışmak zorunda kalan kişilerde gözlemlenen, umutsuz ve çaresiz hissetme, fiziksel yorgunluk, uzun süren halsizlik gibi belirtiler sonucunda bireyde meydana gelen, iş hayatına ve sosyal çevreye karşı olumsuz yaklaşımlarla kendini gösteren bir sendrom" olarak tanımlamıştır (Maslach \& Jackson, 1981).

Tükenmişliğin yalnızca bir işyeri ortamında veya bir meslekte çalışan kişilerde değil, aynı zamanda öğrencilerde de oldukça fazla etki gösterebileceği düşünülebilir. Öğrencilerin kendilerinden beklenen akademik sorumlulukları yerine getirme, sınavlara çalışma, derse katılım sağlama gibi davranışları onların işi gibi görülebilir (Breso, Salanova \& Schaufeli, 2007: s.462). Bu bağlamda insanlarla bir arada çalışılan mesleklerde daha fazla görülen tükenmişlik, öğrenciler açısından da bir risk oluşturabilir.

Okul tükenmişliği, genel eğitim hayatının ve okulların aşırı beklentilerinin öğrencileri zihinsel, bedensel ve duygusal olarak bitkin bırakmasını veya yıpratmasını ifade etmektedir (Aypay ve Eryılmaz, 2011). Ülkemizdeki eğitim sisteminde; temel eğitim, lise, üniversite ve meslek öncesi dönemlerde sınavların yoğun olduğu zorlayıcı bir yarışmanın varlı̆ından söz etmek mümkündür. Bu nedenle, öğrencilerin bu eğitim-öğretim kademelerinde kariyer planlaması yapmaları oldukça stresli ve sıkıntılı bir hale gelmektedir (Çapri, Gündüz ve Gökçakan, 2011). Tükenmişlik hissi yaşayan öğrencilerde okuldan ayrılma davranışı görülebilir. Okuldan ayrılmayıp devam edenlerde ise ilgisizlik, çalışmamayı isteme, hoşnutsuzluk, can sıkıntısı görülebilmektedir. Diğer yandan tükenmiş kişi, yaşadığı bireysel çatışmalar ve sorumluluklarını yerine getirmeme gibi nedenlerle arkadaşlarını da kötü yönde etkileyebilmektedir (Şimşek-Bekir, Şahin ve Şanlı, 2012). Derslere ve okula karşı tükenmişlik duygusu yaşayan öğrencilerde sınıf faaliyetlerine katılım sağlamama, derslere devam etmek istememe, yürütülen etkinlikleri anlamsız bulma, öğretilmek istenen yeni bilgilere duyarsız kalma, kendini engellenmiş hissetme gibi davranışlar görülebilir (Jacobs \& Dodd, 2003).

Bazı araştırmacılar tarafından öğrencilerin tükenmişlik düzeyleri ile ilgili yapılan araştırmalarda üniversite öğrencilerinin tükenmişliğini etkileyen etmenler; farklı eğitim kademelerine ve farklı sınıflara uyum sağlama, akademik baskıların ve yüklerin artması, öğrencilerin birbirleriyle etkileşimleri, aşk ilişkileri, sevgili sorunları, zamanı ve öğrenme sürecini yönetememe, akranlarla yaşanan rekabet, finansal sıkıntılar, dostlukların zedelenmesi şeklinde sıralanmıştır (Cushman \& West, 2006; Dyrbye, Thomas, Huntington, Lawson, Novotny, Sloan \& Shanafelt, 2006; Weckwerth \& Flynn, 2006).

Okul tükenmişliği üzerine yapılan araştırmalar incelendiğinde öğrencilerin tükenmişlik düzeylerinin akademik performans ve okul bağlılık düzeyi (Schaufeli, Martinez, Pinto, Salanova \& Bakker, 2002), stres seviyesi ve akademik ilgi (Durán, Extremera, Rey, Fernández-Berrocal \& Montalbán, 2006), olumsuz kişisel yaşantılar (Dyrbye, vd., 2006), geleceğe yönelik endişe taşıma durumu (Erturgut ve Soyşekerci, 2010), kendini mesleğe hazır hissetme, mesleğin toplumdaki değeri (Çavuşoğlu, 2009) gibi farklı değişkenler ile ilişkili olduğu sonuçları elde edilmiştir.

Tükenmişliğin ortaya çıkma nedenleri ile benzer olan çağımııın bir diğer sosyal problemi yabancılaşmadır (Özçınar, 2011). Yabancılaşma; kişilerin başkalarından, birbirlerinden veya belirli ortam ya da süreçlerden uzaklaşmaları (Marshall, 1999, s.798) olarak tanımlanabilir.

Yabancılaşma kavramı, özellikle içinde bulunduğumuz sanayi toplumlarında insan ilişkilerini ve tüm kurumları büyük ölçüde etkilemektedir. Eğitim alanı da yabancılaşma sorunundan en çok etkilenen alanlardan biri haline gelmiştir (Tezcan, 1997, s.245). Yabancılaşmanın birçok araştırmacı tarafından ele alınmasının ve yeni bir kavram olmayışının yanı sıra "okula yabancılaşma", göreceli olarak literatüre yeni giren bir kavram olup öğrencilerin davranışlarını anlamlandırma noktasında önemlidir (Trusty \& Dooley-Dickey, 1993).

Okula yabancılaşma, öğrencinin okulun yapısına, yakın çevresine, diğer öğrencilere ve eğitimcilere olan bağlıı̆ını kaybetmesidir (Warner, Weist \& Krulak, 1999). Bir başka açıdan okula yabancılaşma kavramı, öğretme-öğrenme süreçleri ve onun kurumsal alt yapısını meydana getiren normlar, değerler, etkileşimler, davranış örüntüleri, sosyal ilişkiler ile ilişkilidir (Katıtaş, 2012). 
Okula yabancılaşma konusuna yönelik olarak yapılan araştırmalarda, sınıfların kalabalık olmasının, okullardaki bürokratik yapının, ders programlarının yoğun olmasının, eğitim süreçlerine öğrencilerin dahil edilmemesinin, demokratik yönetim anlayışının benimsenmemesinin, öğrencilere gerçek yaşamın dışından gereksiz bilgi yüklemesi yapılmasının öğrencilerin yabancılaşmalarına yol açan faktörler olduğu belirtilmiştir (Erjem, 2005). Parsıl'a (2007) göre, kitle iletişim araçları, akran grupları ve aile gibi dış (çevresel) faktörlerin yanında sınıfın fiziksel yeterliliği, sınıf yönetimi anlayışı, çalışma koşulları (estetik, sınıfın büyüklüğü, aydınlatma, yerleşim düzeni, gürültü), ekonomik ve teknolojik yapı, iş bölümü, kültürel yapı, bilgi akışı ve iletişim gibi iç (örgütsel) faktörler okullarda öğrencilerin yabancılaşma düzeylerini etkilemektedir.

Okula karşı yabancılaşan öğrencilerde okul yaşantılarını olumsuz algılama durumu görülebilir. Bu öğrenciler okula aidiyetlik duygularını kaybetmelerinin yanı sıra okul ortamının kendilerini tehdit edici bir ortam olduğunu düşünebilirler. Buradan yola çıkılarak okula yabancılaşmanın okul öfkesi açısından risk faktörü olduğu söylenebilir (Çivitci, 2011). Tarquin \& Cook-Cottone (2008) öğrenci yabancılaşması üzerine yaptıkları bir araştırmalarında okula yabancılaşan öğrencilerin yalnızca derslerden ve öğrenim sürecinden değil; aynı zamanda okuldaki diğer öğrencilerden, tüm okul personelinden, okul yöneticilerinden, okuldaki sosyal faaliyetlerden (öğrenci toplulukları, spor etkinlikleri, sınıf içi ve dışı faaliyetler, arkadaşlık ilişkileri) de uzaklaşacaklarını belirtmişlerdir.

Okula yabancılaşma üzerine yapılan araştırmalar incelendiğinde öğrencilerin yabancılaşma düzeylerinin iş bulamama kaygısı (Repetowski, 1989), çocukluğu mutsuz geçirme, yalnızlık düzeyi, eğitim alınan bölümden memnun olup olmama (Duru, 1995), mesleğe karşı tutum (Çağlar, 2013), akademik öz yeterlilik inancı (Polat, Dilekmen ve Yasul, 2015) gibi farkı değişkenler ile ilişkili olduğu sonuçlarına ulaşılmıştır.

Eğitim alanında özellikle öğretmen adayları üzerinde önemli etkilere sahip olan okul tükenmişliği ve okula yabancılaşma sorunları öğrencinin okuluna, kendisine verilen eğitime, icra edeceği mesleğe, yeni bilgiler öğrenmeye, içinde bulunduğu çevreye ve hatta kendisine karşı olumsuz tutum geliştirmesine neden olabilir. Üniversite öğrencilerindeki yabancılaşma ve tükenmişlik ilişkisi ile ilgili araştırmalar incelendiğinde ise eğitim sektöründe iki değişkenin birlikte ele alındığı yalnızca bir araştırmaya (Tümkaya, 2016) rastlanmıştır. Bu araştırma sınıf öğretmenliği bölümünde eğitim alan öğrencilerle yapılmıştır. Öğrencilerin yalnızca cinsiyet ve sınıf düzeyi değişkenlerine göre yabancılaşma ve tükenmişlik düzeyleri ayrı ayrı incelenirken; iki değişkenin birbirini etkileyip etkilemediği de araştırımıştır. Araştırma sonucunda iki değişken arasında pozitif yönlü bir ilişki olduğu sonucuna varılmıştır.

Üniversite öğrencilerinin okul tükenmişliği ve okula yabancılaşması üzerine yapılan araştırmalarda okul öncesi eğitim alanına yönelik yapılmış bir çalışmaya rastlanmamıştır. Bu nedenle bu araştırma son sınıftaki okul öncesi öğretmen adaylarının okul tükenmişliği ve okula yabancılaşma düzeylerinin belirlenmesi, gelecekte gerekli önlemlerin alınması, ilgili problemlere çeşitli çözüm önerileri getirilebilmesi, üniversitelerde öğretmen adaylarına verilen eğitimin kalitesinin artıııması ve okul öncesi eğitim alanına sunacağı katkılar açısından önem taşımaktadır. Araştırmada son sınıftaki okul öncesi öğretmen adaylarının okul tükenmişliği ve okula yabancılaşma düzeylerinin belirlenmesi ve farklı değişkenler açısından incelenmesi amaçlanmıştır. Bu amaçla aşağıdaki araştırma sorularına yanıtlar aranmıştır:

Son sınıftaki okul öncesi öğretmen adaylarının okul tükenmişliği düzeyleri ne durumdadır ve üniversite türü, mezun olunan lise türü, mezun olunan üniversite sayısı değişkenlerine göre farklılaşmakta mıdır?

Son sınıftaki okul öncesi öğretmen adaylarının okul tükenmişliği düzeyleri ile yaşları arasında anlamlı bir ilişki var mıdır?

Son sınıftaki okul öncesi öğretmen adaylarının okula yabancılaşma düzeyleri ne durumdadır ve üniversite türü, mezun olunan lise türü, mezun olunan üniversite sayısı değişkenlerine göre farklılaşmakta mıdır?

Son sınıftaki okul öncesi öğretmen adaylarının okula yabancılaşma düzeyleri ile yaşları arasında anlamlı bir ilişki var midır?

\section{Yöntem}

\section{Araştırmanın Modeli}

Bu çalışma son sınıftaki okul öncesi öğretmen adaylarının okul tükenmişliği ve okula yabancılaşma düzeylerinin farklı değiş̧kenler açısından incelendiği ilişkisel tarama modeline göre planlanmış betimsel bir araştırmadır. 


\section{Evren ve Örneklem}

Bu araştırmanın evrenini 2017-2018 eğitim öğretim yılında İstanbul ili içindeki devlet üniversitelerinde ve özel üniversitelerde Okul Öncesi Eğitimi bölümünde öğrenim görmekte olan 494 son sınıf öğrencisi oluşturmaktadır. Bu öğrencilerden 210 'u devlet üniversitelerinde, 284'ü özel üniversitelerde öğrenim görmektedir. Örneklem büyüklüğü hesaplama formülü sonucunda 2017 yılı Güz döneminde devlet üniversitelerine ait örneklem büyüklüğünün 136; özel üniversitelere ait örneklem büyüklüğünün 165 olduğu belirlenmiştir. Araştırma kapsamında toplamda 361 öğrenciye ulaşılmış ancak; 32 veri kaybı tespit edildiğinden dolayı ulaşılan öğrenci sayısı 329'a düşmüştür. Ulaşılan 329 öğrenciden 300'ü kız, 29'u erkek öğrencidir. Kız ve erkek öğrenci sayısı arasındaki bu büyük farkın dağılımda ve istatistiksel analizlerde sapmalara neden olabileceği düşüncesi nedeniyle 29 erkek öğrenci örnekleme dahil edilmemiştir. Böylelikle araştırmaya katılan öğrencilerin sayısı 300 olup tümü kız öğrencidir.

Aşağıda bulunan Tablo 1'de araştırmaya katılan öğrencilerin algıladıkları sosyoekonomik düzeylere ve öğrenim gördükleri üniversite türlerine ait yüzde ve frekans dağılımları sunulmuştur.

Tablo 1. Araştırmaya Katılan Öğrencilere Ait Sosyoekonomik Düzey ve Öğrenim Görülen Üniversite Türüne ilişskin Yüzde ve Frekans Dağılımları

\begin{tabular}{lllllllll}
\hline & \multicolumn{3}{c}{ Öğrencilerin Sosyoekonomik Düzeyleri } & \multicolumn{3}{c}{ Toplam } \\
\cline { 2 - 7 } & Alt & \multicolumn{4}{c}{ Orta } & Üst & & \\
\cline { 2 - 7 } & $\mathrm{f}$ & $\%$ & $\mathrm{f}$ & $\%$ & $\mathrm{f}$ & $\%$ & $\mathrm{f}$ & $\%$ \\
Devlet & 10 & 3,3 & 125 & 41,7 & 2 & 0,6 & 137 & 45,7 \\
Özel & 1 & 0,3 & 134 & 44,7 & 28 & 9,4 & 163 & 54,3 \\
Toplam & 11 & 3,6 & 259 & 86,4 & 30 & 10 & 300 & 100 \\
\hline
\end{tabular}

Tablo 1'de görüldüğü üzere hem devlet üniversitelerindeki hem de özel üniversitelerdeki öğrencilerin büyük bir çoğunluğu kendilerini orta sosyoekonomik düzey grubuna ait hissetmektedir. Bu nedenle araştırmada örneklem grubu orta sosyoekonomik düzey olarak kabul edilmiş ve veri analizlerinde sosyoekonomik düzey değişkeni ele alınmamıştır.

\section{Veri Toplama Araçları}

\section{Kişisel Bilgi Formu}

$\mathrm{Bu}$ form araştırmacı tarafından hazırlanan, örneklem grubunun demografik özelliklerinin bulunduğu ve araştırmanın bağımsız değişkenlerinin yer aldığı bir ankettir. Formda üniversite adı, ölçek uygulama tarihi, doğum tarihi, mezun olunan lise adı, eğitim alınan üniversite sayısı gibi durumlara yönelik sorular bulunmaktadır.

\section{Öğrenci Yabancılaşma Ölçeği}

Araştırmada son sınıfta okul öncesi öğretmen adayı olan üniversite öğrencilerinin yaşadıkları okula yabancılaşma düzeylerini belirlemek için Çağlar (2012) tarafından üniversite öğrencileri için geliştirilen "Öğrenci Yabancılaşma Ölçeği" kullanılmıştır. Öğrenci Yabancılaşma Ölçeği, toplamda 20 madde olup dört alt boyuttan oluşmaktadır. Bu alt boyutlara göre madde sayıları; güçsüzlük 6 madde, kuralsızlık 4 madde, soyutlanmışlık 5 madde ve anlamsızlık 5 madde olarak gösterilmiştir. Ölçekle ilgili olarak iç tutarlılık katsayıları incelendiğinde; güçsüzlük için .79, kuralsızlık için .75, soyutlanmışlık için .76, anlamsızlık için .76, genel okula yabancılaşma için .86'dır. Ölçekte bulunan 20 maddeden 9'u yabancılaşma yaşanmadığına, $11^{\prime} i$ yabancılaşma yaşandığına ilişkin maddelerdir (Çağlar, 2013). Ölçek maddelerinin yanıtlanma şekli "1=kesinlikle katılmıyorum, 2=katılmıyorum, 3=kararsızım, 4=katılıyorum, 5=kesinlikle katılıyorum" olarak beşli derecelendirme şeklinde geliştirilmiştir. Ölçekten alınabilecek en düşük puan 20 iken en yüksek puan 120 'dir (Polat, Dilekmen ve Yasul, 2015). Alınan puan ne kadar yüksekse öğrenci o kadar yüksek düzeyde yabancılaşma yaşamaktadır. Benzer şekilde düşük puan da daha az yabancılaşma yaşandığını belirtmektedir (Çağlar, 2013). Ölçeğin puan aralıklarına göre (1.00-1.79) arasında oldukça düşük, (1.80-2.59) arasında düşük, (2.60-3.40) arasında orta, (3.414.21) arasında yüksek, (4.22-5.00) arasında oldukça yüksek düzey yabancılaşma yaşanmaktadır (Polat, Dilekmen ve Yasul, 2015).

\section{Maslach Tükenmişlik Envanteri Öğrenci Versiyonu}

Maslach Tükenmişlik Envanteri Öğrenci Versiyonu üniversite öğrencilerinin okul tükenmişliği düzeylerini ölçmek için Schaufeli vd. (2002) tarafından geliştirilmiştir. Ölçek 7'li likert tipinde 15 maddeliktir ve ölçeğin üç alt boyutu bulunmaktadır. Bunlar; duygusal tükenme, duyarsızlık, akademik yeterliliktir. Ölçekteki tüm maddelerin toplamından öğrencilerin genel okul tükenmişliği düzeyleri, her bir alt boyuttaki maddelerin toplamından da o alt boyuta ait 
düzeyleri belirlenmektedir. Ölçeğin iç tutarlılık katsayıları incelendiğinde; duygusal tükenme için $\alpha=, 80$; duyarsızlık için $\alpha=, 86$; akademik yeterlilik için $\alpha=, 67$ olduğu görülmektedir. Ölçekten alınan yüksek puanlar yüksek düzeyde tükenmişlik yaşandığını belirtmektedir (Schaufeli vd., 2002; akt. Balkıs, Duru, Buluş ve Duru, 2011). Schaufeli vd. (2002) tarafından geliştirilen Maslach Tükenmişlik Envanteri-Öğrenci Formu (MTE-ÖF)'nun Türkçe uyarlaması Çapri, Gündüz ve Gökçakan (2011) tarafından yapılmıştır. Ölçeğin uyarlanmasında 782 üniversite öğrencisi ile çalışılmıştır. Yapı geçerliğini belirlemek için yapılan doğrulayıcı faktör analizi sonucunda, üç alt boyuttan ve toplam 13 maddeden oluşan ölçeğe son hali verilmiştir. Elde edilen alt boyutlar ve maddeleri şu şekilde sıralanmaktadır: tükenme= 5 madde, duyarsılaşma $=4$ madde, yetkinlik= 4 madde. Bu alt boyutların puanları arasındaki korelasyonlar 0,32 ile 0,83 arasında değişmektedir. Madde geçerliği için madde toplam test korelasyonları incelenmiştir. Bu analiz sonucuna göre alt boyutların korelasyon değerleri 0,32 ile 0,69 arasında değişmektedir. Çapri, Gündüz ve Gökçakan (2011) üniversite öğrencileri ile gerçekleştirdikleri ölçek uyarlama çalışmalarında, MTE-ÖF'nin orijinalindeki gibi üç alt boyutlu yapıya ulaşabildiklerini ancak; orijinalinde 16 madde olan ölçeğin uyarlama sonucunda 13 maddeye indirildiğini belirtmişlerdir.

\section{Verilerin Toplanması ve Analizleri}

2017-2018 eğitim öğretim yılında İstanbul'daki üniversiteler arasından Okul Öncesi Eğitimi bölümünde son sınıf öğrencileri bulunan 3 devlet üniversitesi ve 6 özel üniversite tespit edilmiştir. İrtibata geçilen özel üniversitelerden 2'si bölüm öğrencilerine ölçeklerin uygulanmasını uygun görmeyerek araştırmaya katılmamıştır. Uygulamanın yapılmasını onaylayan 7 üniversiteden gerekli izinler alınmıştır. Öğretim elemanları ile iş birliği yapılarak araştırmacı tarafından okullara gidilmiş ve öğrencilere ölçekler grup halinde uygulanmıştır. Araştırmada öncelikle verilerin normal dağılım gösterip göstermediğini istatistiksel anlamda belirlemek amacıyla Kolmogorov-Smirnov normallik testi uygulanmıştır ve yapılan test sonucunda verilerin normal dağılım gösterdiği sonucuna ulaşıımıştır $(p>, 05)$. Veri analizlerinde parametrik testlerden Bağımsız Gruplar t-Testi, Tek Faktörlü Varyans Analizi, Scheffe ve Pearson testi uygulanmıştır.

\section{Bulgular}

Aşağıdaki Tablo 2'de son sınıftaki okul öncesi öğretmen adaylarının okul tükenmişliği ölçeğinden aldıkları toplam puanlara ilişkin frekans ve yüzde değerleri verilmiştir. Maslach Tükenmişlik Envanteri Öğrenci Formu'ndan bağımsız olarak, araştırmacı tarafından tükenmişlik düzeylerinin sınıflandırılması düşüncesi geliştirilmiş ve bu konuda iki uzmana danışılmıştır. Ölçekten elde edilen minimum ve maksimum puanlara göre kesim noktaları belirlenerek "düşük-ortayüksek düzey tükenmişlik" kategorileri oluşturulmuştur.

Tablo 2. Son Sınıftaki Okul Öncesi Öğretmen Adaylarının Maslach Tükenmişlik Envanteri Öğrenci Formu'ndan Aldıkları Toplam Puanlara İlişkin Frekans ve Yüzde Değerleri

\begin{tabular}{lll}
\hline Tükenmişlik düzeyi & $\mathbf{f}$ & $\mathbf{\%}$ \\
\hline 13-30 puan aralığı (düşük) & 99 & 33 \\
31-48 puan aralığı (orta) & 161 & 53,7 \\
49-65 puan aralığı (yüksek) & 40 & 13,3 \\
Toplam & 300 & 100 \\
\hline
\end{tabular}

Tablo 2'ye göre son sınıftaki okul öncesi öğretmen adaylarının 99'unun okul tükenmişliği ölçeğinden aldıkları toplam puan 13 ile 30 puan arasında; 161'inin 31 ile 48 puan arasında; 40'ının da 49-65 puan arasında olduğu görülmektedir. Buradan hareketle son sınıftaki okul öncesi öğretmen adaylarının \%33'ünün düşük düzeyde, \%53,7'sinin orta düzeyde ve \%13,3'ünün yüksek düzeyde okul tükenmişliği yaşadıkları söylenebilir. 
Tablo 3. Üniversite Türüne Göre Maslach Tükenmişlik Envanteri Öğrenci Formu Genel ve Alt Ölçek Puanları Arasındaki Farklara İlişkin Bağımsız Gruplar t-Testi Sonuçları

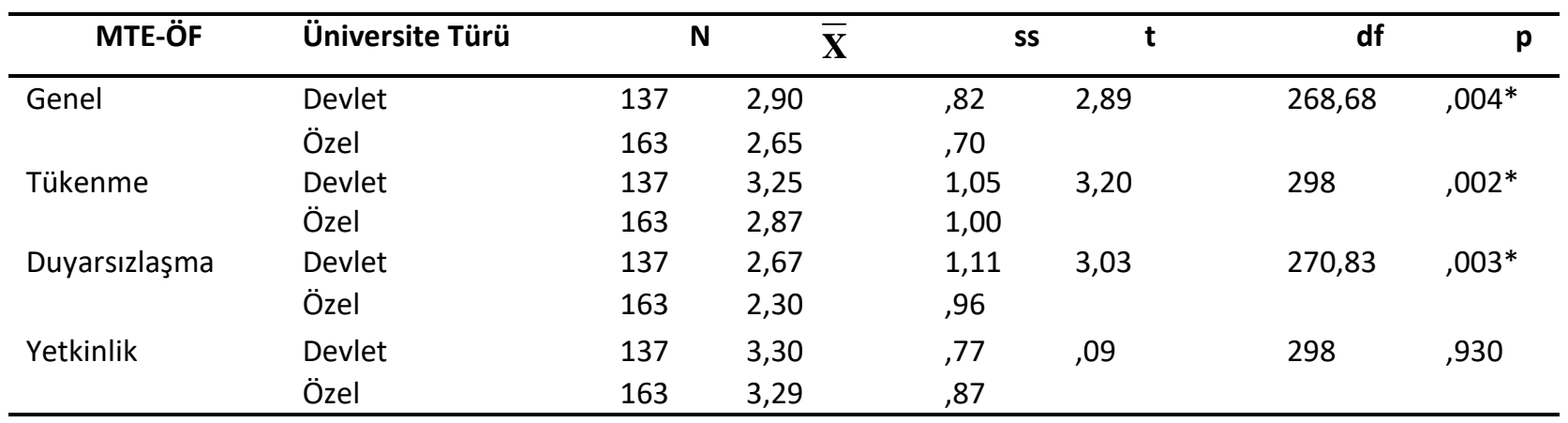

$*<0,01$ düzeyinde istatistiksel olarak anlamlıdır.

Tablo 3'e göre devlet üniversitelerinde ve özel üniversitelerde öğrenim görmekte olan öğrencilerin toplam okul tükenmişliği puanları, tükenme alt boyutu puanları ve duyarsızlaşma alt boyutu puanları arasında istatistiksel olarak anlamlı farklııklar vardır (Genel; $\mathrm{t}(268,68)=2,89$; pgenel<,01; Tükenme; $\mathrm{t}(298)=3,20 ;$ ptükenme<,01; Duyarsızlaşma; $\mathrm{t}(270,83)=3,03$; pduyarsızlaşma $<, 01)$.

Buna göre ortalamalara bakıldığında devlet üniversitelerinde öğrenim görmekte olan öğrencilerin genel okul tükenmişliği, tükenme ve duyarsızlaşma düzeyleri özel üniversitelerdeki öğrencilere göre daha yüksektir (Genel; $\overline{\mathrm{X}}$ devlet=2,90, ss=,82; $\bar{X}_{\text {özel=2,65, ss=,70; Tükenme; }} \bar{X}_{\text {devlet=3,25, ss=1,05; }} \bar{X}_{\text {özel=2,87, ss=1,00; Duyarsılaş̧ma; }} \bar{X}$

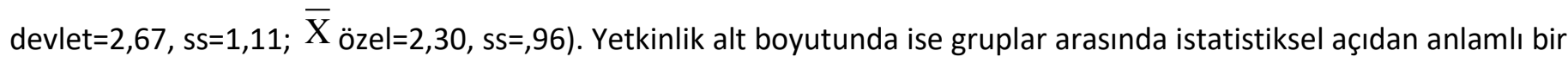
farklılık bulunmamıştır $(p>, 05)$.

Tablo 4. Mezun Olunan Lise Türüne göre Maslach Tükenmişlik Envanteri Öğrenci Formu Genel Ölçek Puanları Arasındaki Farklara i̇lişkin Tek Faktörlü Varyans Analizi Sonuçları

\begin{tabular}{lllllll}
\hline MTE-ÖF & Lise Türü & N & $\bar{X}$ & Ss & F & p \\
\hline Genel & Anadolu Lisesi & 53 & 2,82 &, 79 & 3,34 &, $011^{*}$ \\
& Genel Lise & 37 & 2,58 &, 66 & & \\
& Anadolu Öğretmen Lisesi & 67 & 3,03 &, 76 & & \\
& Meslek Lisesi & 98 & 2,67 &, 79 & & \\
& Kolej & 45 & 2,66 &, 66 & & \\
\hline
\end{tabular}

$*<0,05$ düzeyinde istatistiksel olarak anlamlıdır.

Tablo 4'te görüldüğg̈ gibi öğrencilerin mezun oldukları lise türüne göre genel okul tükenmişliği düzeyleri anlamlı bir farklılık göstermektedir $(p<, 05)$.

Grup homojen dağıım gösterdiğinden farklılıkların yönünü bulmak amacıyla Scheffe testi uygulanmış ve analiz sonuçları Tablo 5'te sunulmuştur. 
Tablo 5. Mezun Olunan Lise Türüne göre Maslach Tükenmişlik Envanteri Öğrenci Formu Genel Ölçek Puanları Arasındaki Farklara iliş̧in Scheffe Sonuçları

\begin{tabular}{|c|c|c|c|c|}
\hline MTE-ÖF & & Lise Türü & $\mathbf{X I - X J}$ & $\mathbf{p}$ \\
\hline \multirow[t]{20}{*}{ Genel } & Anadolu Lisesi & Genel Lise & ,24 & 688 \\
\hline & & Anadolu Öğretmen Lisesi &,- 21 & 689 \\
\hline & & Meslek Lisesi & 15 & ,832 \\
\hline & & Kolej & 16 & 892 \\
\hline & Genel Lise & Anadolu Lisesi &,- 24 & 688 \\
\hline & & Anadolu Öğretmen Lisesi &,- 45 &, $041^{*}$ \\
\hline & & Meslek Lisesi &,- 09 & ,986 \\
\hline & & Kolej &,- 08 & 993 \\
\hline & Anadolu & Anadolu Lisesi & ,21 & 689 \\
\hline & Öğretmen Lisesi & Genel Lise & ,45 &, $041^{*}$ \\
\hline & & Meslek Lisesi & ,36 & ,025* \\
\hline & & Kolej & ,37 & 170 \\
\hline & Meslek Lisesi & Anadolu Lisesi & -15 & 832 \\
\hline & & Genel Lise & ,09 & 986 \\
\hline & & Anadolu Öğretmen Lisesi &,- 36 & ,025* \\
\hline & & Kolej & ,01 & 1,00 \\
\hline & Kolej & Anadolu Lisesi & -16 & 892 \\
\hline & & Genel Lise & ,08 & 993 \\
\hline & & Anadolu Öğretmen Lisesi &,- 37 & 170 \\
\hline & & Meslek Lisesi &,- 01 & 1,00 \\
\hline
\end{tabular}

$*<0,05$ düzeyinde istatistiksel olarak anlamlıdır.

Tablo 5'e göre Anadolu öğretmen lisesi mezunu olan öğrencilerin genel okul tükenmişliği düzeyleri genel lise mezunlarına göre daha yüksek çıkmıştır $(p<, 05 ; \mathrm{XI}-\mathrm{XJ}=, 45$; (öğretmenlisesi>genellise). Benzer şekilde Anadolu öğretmen lisesinden mezun olanların genel okul tükenmişliği düzeyleri meslek lisesinden mezun olanlara göre de daha yüksek bulunmuştur ( $\mathrm{p}<, 05 ; \mathrm{XI}-\mathrm{XJ}=, 36$; (öğretmenlisesi>mesleklisesi).

Tablo 6. Mezun Olunan Lise Türüne göre Maslach Tükenmişlik Envanteri Öğrenci Formu Tükenme Alt Ölçek Puanları Arasındaki Farklara iliş̧kin Tek Faktörlü Varyans Analizi Sonuçları

\begin{tabular}{lllllll}
\hline MTE-ÖF & Lise Türü & $\mathbf{N}$ & $\overline{\mathbf{X}}$ & Ss & $\mathbf{F}$ & $\mathbf{p}$ \\
\hline Tükenme & Anadolu Lisesi & 53 & 3,12 & 1,04 & 3,39 &, $012^{*}$ \\
& Genel Lise & 37 & 2,87 &, 96 & & \\
& Anadolu Öğretmen Lisesi & 67 & 3,42 & 1,03 & & \\
& Meslek Lisesi & 98 & 2,92 & 1,05 & & \\
& Kolej & 45 & 2,83 &, 99 & & \\
\hline
\end{tabular}

$*<0,05$ düzeyinde istatistiksel olarak anlamlıdır.

Tablo $6^{\prime}$ da görüldüğü gibi öğrencilerin mezun oldukları lise türüne göre tükenme alt boyutu düzeyleri anlamlı bir farklılık göstermektedir $(p<, 05)$.

Grup homojen dağılım gösterdiğinden farklııkların yönünü bulmak amacıyla Scheffe testi uygulanmış ve analiz sonuçları Tablo 7'de sunulmuştur. 
Tablo 7. Mezun Olunan Lise Türüne göre Maslach Tükenmişlik Envanteri Öğrenci Formu Tükenme Alt Ölçek Puanları Arasındaki Farklara iliş̧in Scheffe Sonuçları

\begin{tabular}{|c|c|c|c|c|}
\hline MTE-ÖF & & Lise Türü & $\mathbf{X I}-\mathbf{X J}$ & $\mathbf{p}$ \\
\hline \multirow[t]{20}{*}{ Tükenme } & Anadolu Lisesi & Genel Lise & 24 & 871 \\
\hline & & Anadolu Öğretmen Lisesi &,- 30 & ,648 \\
\hline & & Meslek Lisesi & ,20 & ,850 \\
\hline & & Kolej & ,28 & ,758 \\
\hline & Genel Lise & Anadolu Lisesi &,- 24 & ,871 \\
\hline & & Anadolu Öğretmen Lisesi &,- 54 & ,158 \\
\hline & & Meslek Lisesi &,- 04 & 1,00 \\
\hline & & Kolej & ,04 & 1,03 \\
\hline & Anadolu & Anadolu Lisesi & 30 & ,648 \\
\hline & Öğretmen Lisesi & Genel Lise &, 54 & ,158 \\
\hline & & Meslek Lisesi &, 50 & ,038* \\
\hline & & Kolej & ,58 & ,073 \\
\hline & Meslek Lisesi & Anadolu Lisesi & ,17 & ,850 \\
\hline & & Genel Lise & ,04 & 1,00 \\
\hline & & Anadolu Öğretmen Lisesi &,- 50 & ,038* \\
\hline & & Kolej & 08 & ,996 \\
\hline & Kolej & Anadolu Lisesi &,- 28 & ,758 \\
\hline & & Genel Lise &,- 04 & 1,03 \\
\hline & & Anadolu Öğretmen Lisesi &,- 58 & ,073 \\
\hline & & Meslek Lisesi &,- 08 & ,996 \\
\hline
\end{tabular}

*<0,05 düzeyinde istatistiksel olarak anlamlıdır.

Tablo 7'ye göre Anadolu öğretmen lisesi mezunu olan öğrencilerin tükenme alt boyutu düzeyleri meslek lisesi mezunlarına göre daha yüksek çıkmıştır ( $p<, 05 ; \mathrm{XI-XJ=,50;} \mathrm{öğretmenlisesi>mesleklisesi).}$

Tablo 8. Mezun Olunan Lise Türüne göre Maslach Tükenmişlik Envanteri Öğrenci Formu Duyarsızlaşma Alt Ölçek Puanları Arasındaki Farklara illişkin Tek Faktörlü Varyans Analizi Sonuçları

\begin{tabular}{lllllll}
\hline MTE-ÖF & Lise Türü & $\mathbf{N}$ & $\bar{X}$ & Ss & F & p \\
\hline Duyarsızlaşma & Anadolu Lisesi & 53 & 2,51 & 1,12 & 2,45 &, 067 \\
& Genel Lise & 37 & 2,17 &, 96 & & \\
& Anadolu Öğretmen Lisesi & 67 & 2,78 & 1,07 & & \\
& Meslek Lisesi & 98 & 2,40 &, 99 & & \\
& Kolej & 45 & 2,39 & 1,04 & & \\
\hline
\end{tabular}

Tablo 8' de görüldüğü gibi öğrencilerin mezun oldukları lise türüne göre duyarsızlaşma alt boyutu düzeyleri anlamlı bir farklılık göstermemektedir $(p>, 05)$.

Tablo 9. Mezun Olunan Lise Türüne göre Maslach Tükenmişlik Envanteri Öğrenci Formu Yetkinlik Alt Ölçek Puanları Arasındaki Farklara İlişkin Tek Faktörlü Varyans Analizi Sonuçları

\begin{tabular}{lllllll}
\hline MTE-ÖF & Lise Türü & $\mathbf{N}$ & $\overline{\mathbf{X}}$ & Ss & $\mathbf{F}$ & $\mathbf{p}$ \\
\hline Yetkinlik & Anadolu Lisesi & 53 & 3,24 &, 82 &, 61 &, 654 \\
& Genel Lise & 37 & 3,38 &, 66 & & \\
& Anadolu Öğretmen Lisesi & 67 & 3,20 &, 73 & & \\
& Meslek Lisesi & 98 & 3,37 &, 87 & & \\
& Kolej & 45 & 3,28 &, 98 & & \\
\hline
\end{tabular}

Tablo 9'da görüldüğü gibi öğrencilerin mezun oldukları lise türüne göre yetkinlik alt boyutu düzeyleri anlamlı bir farklılık göstermemektedir $(p>, 05)$. 
Tablo 10. Eğitim Alınan Üniversite Sayısına göre Maslach Tükenmişlik Envanteri Öğrenci Formu Genel ve Alt Ölçek Puanları Arasındaki Farklara i̇lişkin Bağımsız Gruplar t-Testi Sonuçları

\begin{tabular}{|c|c|c|c|c|c|c|c|}
\hline MTE-ÖF & Üniversite Sayısı & $\mathbf{N}$ & $\overline{\mathrm{X}}$ & SS & $\mathbf{T}$ & df & $\mathbf{p}$ \\
\hline \multirow[t]{2}{*}{ Genel } & 1 & 230 & 2,75 & ,76 &,- 43 & 298 & ,667 \\
\hline & 1'den fazla & 70 & 2,80 & 79 & & & \\
\hline \multirow[t]{2}{*}{ Tükenme } & 1 & 230 & 3,01 & 1,04 & $-1,01$ & 298 & ,315 \\
\hline & 1'den fazla & 70 & 3,16 & 1,05 & & & \\
\hline \multirow[t]{2}{*}{ Duyarsızlaşma } & 1 & 230 & 2,48 & 1,04 & ,08 & 298 & ,934 \\
\hline & 1'den fazla & 70 & 2,46 & 1,08 & & & \\
\hline \multirow[t]{2}{*}{ Yetkinlik } & 1 & 230 & 3,29 & 81 &,- 18 & 298 & ,854 \\
\hline & 1'den fazla & 70 & 3,31 & 87 & & & \\
\hline
\end{tabular}

Tablo 10’a göre öğrencilerin eğitim aldıkları üniversite sayılarına göre genel okul tükenmişliği, tükenme, duyarsızlaşma ve yetkinlik düzeyleri anlamlı bir farklılık göstermemiştir (pgenel $>, 05$; ptükenme $>, 05$; pduyarsızlaşma $>, 05 ;$ pyetkinlik>,05).

Tablo 11. Yaş Değişkeni ile Maslach Tükenmişlik Envanteri Öğrenci Formu Genel ve Alt Ölçek Puanları Arasındaki ilişkiye Ait Pearson Testi Sonuçları

\begin{tabular}{llllll}
\hline Değişkenler & $\mathbf{N}$ & $\overline{\mathbf{X}}$ & ss & $\mathbf{r}$ & $\mathbf{p}$ \\
\hline Genel & 300 & 2,76 &, 76 &,- 10 &, 071 \\
Yaş & 300 & 22,6 & 1,70 & & \\
Tükenme & 300 & 3,05 & 1,04 &,- 09 &, 109 \\
Yaş & 300 & 22,6 & 1,70 & & \\
Duyarsızlaşma & 300 & 2,47 & 1,05 &,- 08 &, 183 \\
Yaş & 300 & 22,6 & 1,70 & & \\
Yetkinlik & 300 & 3,30 &, 82 &, 07 &, 221 \\
Yaş & 300 & 22,6 & 1,70 & & \\
\hline
\end{tabular}

Tablo 11 'e göre öğrencilerin yaşları ile genel okul tükenmişliği, tükenme, duyarsızlaşma ve yetkinlik düzeyleri arasında anlamlı bir ilişki bulunmamıştır (pgenel >,05; ptükenme>,05; pduyarsızlaşma>,05; pyetkinlik>,05).

Tablo 12. Son Sınıftaki Okul Öncesi Öğretmen Adaylarının Öğrenci Yabancılaşma Ölçeği’nden Aldıkları Toplam Puanlara göre Yabancılaşma Düzeylerine Ait Frekans ve Yüzde Değerleri

\begin{tabular}{lll}
\hline Yabancılaşma düzeyi & $\mathbf{f}$ & \% \\
\hline Oldukça düşük (20-35 puan) & 23 & 7,7 \\
Düşük (36-51 puan) & 91 & 30,3 \\
Orta (52-67 puan) & 134 & 44,7 \\
Yüksek düzey (68-83 puan) & 47 & 15,7 \\
Oldukça yüksek (84-100 puan) & 5 & 1,6 \\
Toplam & 300 & 100 \\
\hline
\end{tabular}

Tablo 12'de görüldüğü üzere son sınıftaki okul öncesi öğretmen adaylarının 23'ünün okula yabancılaşma ölçeğinden aldıkları toplam puan 20-35 arası; 91'inin 36-51 puan arası; 134'ünün 52-67 puan arası; 47'sinin 68-83 puan arası ve 5'inin 84-100 puan arasıdır. Buna göre son sınıftaki okul öncesi öğretmen adaylarının \%7,7'si oldukça düşük; \%30,3'ü düşük; \%44,7'si orta; \%15,7'si yüksek; \%1,6'sı oldukça yüksek düzeyde okula yabancılaşma yaşamaktadır. 
Tablo 13. Üniversite Türüne göre Öğrenci Yabancılaşma Ölçeği Genel ve Alt Ölçek Puanları Arasındaki Farklara illişkin Bağımsız Gruplar t-Testi Sonuçları

\begin{tabular}{|c|c|c|c|c|c|c|c|}
\hline ÖYÖ & Üniversite Türü & $\mathbf{N}$ & $\overline{\mathbf{X}}$ & ss & $t$ & df & $\mathbf{p}$ \\
\hline \multirow[t]{2}{*}{ Genel } & Devlet & 137 & 2,85 & ,71 & 1,73 & 298 & ,084 \\
\hline & Özel & 163 & 2,71 & 62 & & & \\
\hline \multirow[t]{2}{*}{ Güçsüzlük } & Devlet & 137 & 2,45 & ,86 & ,43 & 298 & 669, \\
\hline & Özel & 163 & 2,41 & ,73 & & & \\
\hline \multirow[t]{2}{*}{ Kuralsızlık } & Devlet & 137 & 3,19 & , 88 & 1,11 & 298 & ,269 \\
\hline & Özel & 163 & 3,08 & ,83 & & & \\
\hline \multirow[t]{2}{*}{ Soyutlanmışlık } & Devlet & 137 & 2,64 & 85 & ,45 & 298 & 650 \\
\hline & Özel & 163 & 2,63 & 89 & & & \\
\hline \multirow[t]{2}{*}{ Anlamsızlık } & Devlet & 137 & 3,23 & 99 & 3,67 & 298 &, $000 *$ \\
\hline & Özel & 163 & 2,81 & ,96 & & & \\
\hline
\end{tabular}

$*<0,01$ düzeyinde istatistiksel olarak anlamlıdır.

Tablo 13'te görüldüğü gibi öğrencilerin genel okula yabancılaşma düzeyleri üniversite türü değişkenine göre anlamlı bir farklılık göstermemektedir ( $p>, 05)$. Benzer şekilde güçsüzlük, kuralsızlık, soyutlanmışlık alt boyutlarında da üniversite türüne göre anlamlı bir farklılık yoktur (pgüçsüzlük $>, 05$; pkuralsızlık $>, 05 ;$ psoyutlanmışlık $>, 05$ ). Anlamsızlık alt boyutunda ise devlet üniversitelerinde eğitim alan öğrencilerin lehine olmak üzere iki grup arasında anlamlı bir farklılık vardır $(\mathrm{t}(298)=3,67$; panlamsızlık<,01). Ortalamalara bakıldığında devlet üniversitelerinde eğitim alan

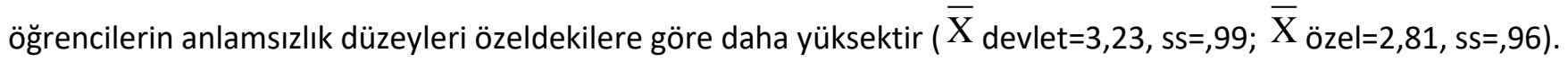

Tablo 14. Mezun Olunan Lise Türüne göre Öğrenci Yabancılaşma Ölçeği Genel Ölçek Puanları Arasındaki Farklara ilişkin Tek Faktörlü Varyans Analizi Sonuçları

\begin{tabular}{lllllll}
\hline ÖYÖ & Lise Türü & $\mathbf{N}$ & $\overline{\mathbf{X}}$ & ss & $\mathbf{F}$ & $\mathbf{p}$ \\
\hline Genel & Anadolu Lisesi & 53 & 2,85 &, 63 & 2,33 &, $046^{*}$ \\
& Genel Lise & 37 & 2,55 &, 68 & & \\
& Anadolu Öğretmen & 67 & 2,93 &, 08 & & \\
& Lisesi & & & & & \\
& Meslek Lisesi & 98 & 2,74 &, 64 & & \\
& Kolej & 45 & 2,72 & 1,00 & & \\
\hline
\end{tabular}

$*<0,05$ düzeyinde istatistiksel olarak anlamlıdır.

Tablo 14'te görüldüğü gibi öğrencilerin mezun oldukları lise türüne göre genel okula yabancılaşma düzeyleri anlamlı farklııklar göstermektedir $(p<, 05)$.

Grup homojen dağııım gösterdiğinden farklııkların yönünü bulmak amacıyla Scheffe testi uygulanmış ve analiz sonuçları Tablo 15 'te sunulmuştur. 
Tablo 15. Mezun Olunan Lise Türüne göre Öğrenci Yabancılaşma Ölçeği Genel Ölçek Puanları Arasındaki Farklara iliş̧kin Scheffe Sonuçları

\begin{tabular}{|c|c|c|c|c|}
\hline ÖYÖ & & Lise türü & $\mathbf{X I - X J}$ & $\mathbf{p}$ \\
\hline \multirow[t]{20}{*}{ Genel } & Anadolu Lisesi & Genel Lise & 31 & ,021* \\
\hline & & Anadolu Öğretmen Lisesi &,- 28 & ,322 \\
\hline & & Meslek Lisesi & 12 & ,895 \\
\hline & & Kolej & 13 & 912 \\
\hline & Genel Lise & Anadolu Lisesi &,- 31 &, $021^{*}$ \\
\hline & & Anadolu Öğretmen Lisesi &,- 38 & ,452 \\
\hline & & Meslek Lisesi &,- 19 & 699 \\
\hline & & Kolej &,- 17 & ,843 \\
\hline & Anadolu & Anadolu Lisesi & ,28 & ,322 \\
\hline & Öğretmen Lisesi & Genel Lise & ,38 & ,452 \\
\hline & & Meslek Lisesi & 19 & ,511 \\
\hline & & Kolej & ,20 & ,628 \\
\hline & Meslek Lisesi & Anadolu Lisesi &,- 12 & ,895 \\
\hline & & Genel Lise & 19 & 699 \\
\hline & & Anadolu Öğretmen Lisesi &,- 19 & ,511 \\
\hline & & Kolej & 01 & 1,00 \\
\hline & Kolej & Anadolu Lisesi &,- 13 & 912 \\
\hline & & Genel Lise & 17 & ,843 \\
\hline & & Anadolu Öğretmen Lisesi &,- 20 & ,628 \\
\hline & & Meslek Lisesi &,- 01 & 1,00 \\
\hline
\end{tabular}

$*<0,05$ düzeyinde istatistiksel olarak anlamlıdır.

Tablo 15 'e göre Anadolu lisesi mezunu olan öğrencilerin genel okula yabancılaşma düzeyleri genel lise mezunlarına göre daha yüksektir $(p<, 05 ; \mathrm{XI}-\mathrm{XJ}=, 31$; Anadolulisesi>genellise). Diğer lise türlerinden mezun olan öğrenciler arasında anlamlı bir farklılık bulunmamıştır.

Tablo 16. Mezun Olunan Lise Türüne göre Öğrenci Yabancılaşma Ölçeği Güçsüzlük Alt Ölçek Puanları Arasındaki Farklara İlişkin Tek Faktörlü Varyans Analizi Sonuçları

\begin{tabular}{lllllll}
\hline ÖYÖ & Lise Türü & $\mathbf{N}$ & $\overline{\mathbf{X}}$ & ss & $\mathbf{F}$ & $\mathbf{p}$ \\
\hline Güçsüzlük & Anadolu Lisesi & 53 & 2,46 &, 82 &, 166 &, 956 \\
& Genel Lise & 37 & 2,35 &, 80 & & \\
& Anadolu & 67 & 2,47 &, 83 & & \\
& Öğretmen Lisesi & & & & & \\
& Meslek Lisesi & 98 & 2,42 &, 78 & & \\
& Kolej & 45 & 2,43 &, 74 & &
\end{tabular}

Tablo $16^{\prime}$ da görüldüğü gibi öğrencilerin mezun oldukları lise türüne göre güçsüzlük alt ölçek düzeyleri anlamlı bir farklılık göstermemektedir $(p>, 05)$.

Tablo 17. Mezun Olunan Lise Türüne göre Öğrenci Yabancılaşma Ölçeği Kuralsızlık Alt Ölçek Puanları Arasındaki Farklara İlişkin Tek Faktörlü Varyans Analizi Sonuçları

\begin{tabular}{lllllll}
\hline ÖYÖ & Lise Türü & $\mathbf{N}$ & $\overline{\mathbf{X}}$ & ss & $\mathbf{F}$ & $\mathbf{p}$ \\
\hline Kuralsızlık & Anadolu Lisesi & 53 & 3,13 &, 88 & 1,589 &, 177 \\
& Genel Lise & 37 & 2,87 &, 83 & & \\
& Anadolu Öğretmen Lisesi & 67 & 3,29 &, 86 & & \\
& Meslek Lisesi & 98 & 3,15 &, 87 & & \\
& Kolej & 45 & 3,04 &, 81 & & \\
\hline
\end{tabular}

Tablo 17 'de görüldüğü gibi öğrencilerin mezun oldukları lise türüne göre kuralsızlık alt ölçek düzeyleri anlamlı bir farklılık göstermemektedir $(p>, 05)$. 
Tablo 18. Mezun Olunan Lise Türüne göre Öğrenci Yabancılaşma Ölçeği Soyutlanmışlık Alt Ölçek Puanları Arasındaki Farklara iliş̧kin Tek Faktörlü Varyans Analizi Sonuçları

\begin{tabular}{llccccc}
\hline ÖYÖ & Lise Türü & $\mathbf{N}$ & $\overline{\mathbf{X}}$ & ss & $\mathbf{F}$ & $\mathbf{p}$ \\
\hline Soyutlanmışlık & Anadolu Lisesi & 53 & 2,81 &, 90 & 1,472 &, 211 \\
& Genel Lise & 37 & 2,54 &, 94 & & \\
& Anadolu Öğretmen Lisesi & 67 & 2,78 &, 83 & & \\
& Meslek Lisesi & 98 & 2,53 &, 85 & & \\
& Kolej & 45 & 2,61 &, 92 & & \\
\hline
\end{tabular}

Tablo 18 ' de görüldüğü gibi öğrencilerin mezun oldukları lise türüne göre soyutlanmışlık alt ölçek düzeyleri anlamlı bir farklılık göstermemektedir ( $p>, 05)$.

Tablo 19. Mezun Olunan Lise Türüne göre Öğrenci Yabancılaşma Ölçeği Anlamsızlık Alt Ölçek Puanları Arasındaki Farklara İlişkin Tek Faktörlü Varyans Analizi Sonuçları

\begin{tabular}{lllllll}
\hline ÖYÖ & Lise Türü & $\mathbf{N}$ & $\overline{\mathbf{X}}$ & ss & $\mathbf{F}$ & $\mathbf{p}$ \\
\hline Anlamsızlık & Anadolu Lisesi & 53 & 3,15 &, 94 & 5,525 &, $000^{*}$ \\
& Genel Lise & 37 & 2,45 &, 84 & & \\
& Anadolu Öğretmen Lisesi & 67 & 3,33 &, 95 & & \\
& Meslek Lisesi & 98 & 2,95 & 1,02 & & \\
& Kolej & 45 & 2,89 &, 97 & & \\
\hline
\end{tabular}

$*<0,01$ düzeyinde istatistiksel olarak anlamlıdır.

Tablo 19'da görüldüğü gibi öğrencilerin mezun oldukları lise türüne göre anlamsızlık alt ölçek düzeyleri anlamlı farklılıklar göstermektedir $(p<, 01)$.

Grup homojen dağılım gösterdiğinden farklııkların yönünü bulmak amacıyla Scheffe testi uygulanmış ve analiz sonuçları Tablo $20^{\prime}$ de sunulmuştur.

Tablo 20. Mezun Olunan Lise Türüne göre Öğrenci Yabancılaşma Ölçeği Anlamsızlık Alt Ölçek Puanları Arasındaki Farklara iliş̧kin Scheffe Sonuçları

\begin{tabular}{lllll}
\hline ÖYö & \multicolumn{1}{c}{ Lise türü } & XI-XJ & \multicolumn{1}{c}{$p$} \\
\hline Anlamsızlık & Anadolu & Genel Lise &, 70 &, $032^{* *}$ \\
& Lisesi & Anadolu Öğretmen Lisesi &,- 18 &, 896 \\
& & Meslek Lisesi &, 20 &, 838 \\
& Kolej &, 26 &, 787 \\
& \multirow{4}{*}{ Genel Lise } & Anadolu Lisesi &,- 70 &, $032^{* *}$ \\
& & Anadolu Öğretmen Lisesi &,- 88 &, $009^{*}$ \\
& & Meslek Lisesi &,- 50 &, 126 \\
& Kolej &,- 44 &, 374 \\
& Anadolu & Anadolu Lisesi &, 18 &, 896 \\
& Öğretmen & Genel Lise &, 88 &, $009^{*}$ \\
& Lisesi & Meslek Lisesi &, 38 &, 185 \\
& Kolej &, 46 &, 231 \\
& Meslek & Anadolu Lisesi &,- 20 &, 838 \\
& Lisesi & Genel Lise &, 50 &, 126 \\
& Anadolu Öğretmen Lisesi &,- 38 &, 185 \\
& Kolej &, 06 &, 998 \\
& Kolej & Anadolu Lisesi &,- 26 &, 787 \\
& Genel Lise &, 44 &, 374 \\
& Anadolu Öğretmen Lisesi &,- 46 &, 231 \\
& Meslek Lisesi &,- 06 &, 998 \\
\hline
\end{tabular}

$*<0,01$ düzeyinde istatistiksel olarak anlamlıdır.

$* *<0,05$ düzeyinde istatistiksel olarak anlamlıdır. 
Tablo 20’ye göre Anadolu öğretmen lisesi mezunu olan öğrencilerin anlamsızlık alt ölçek düzeyleri genel lise mezunu olanlara göre daha yüksektir ( $p<, 01 ; \mathrm{XI} X \mathrm{XJ}=, 88 ;$ öğretmenlisesi $>$ genellise). Anadolu lisesi mezunlarının da genel lise mezunlarına göre anlamsızlık alt ölçek puanları daha yüksek düzeyde bulunmuştur $(p<, 05 ; \quad X I-X J=, 70$; Anadolulisesi>genellise).

Tablo 21. Eğitim Alınan Üniversite Sayısına göre Öğrenci Yabancılaşma Ölçeği Genel ve Alt Ölçek Puanları Arasındaki Farklara İlişkin Bağımsız Gruplar t-Testi Sonuçları

\begin{tabular}{|c|c|c|c|c|c|c|c|}
\hline ÖYÖ & Üniversite Sayısı & $\mathbf{N}$ & $\overline{\mathbf{X}}$ & ss & $t$ & df & $\mathbf{p}$ \\
\hline \multirow[t]{2}{*}{ Genel } & 1 & 230 & 2,78 & ,68 & ,28 & 298 & 780 \\
\hline & $1^{\prime}$ den fazla & 70 & 2,75 & 63 & & & \\
\hline \multirow[t]{2}{*}{ Güçsüzlük } & 1 & 230 & 2,44 & ,79 & ,29 & 298 & ,774 \\
\hline & 1'den fazla & 70 & 2,41 & ,80 & & & \\
\hline \multirow[t]{2}{*}{ Kuralsızlık } & 1 & 230 & 3,11 & 86 &,- 49 & 298 & ,623 \\
\hline & 1'den fazla & 70 & 3,17 & 85 & & & \\
\hline \multirow[t]{2}{*}{ Soyutlanmışlık } & 1 & 230 & 2,68 & 90 & 1,16 & 133,58 & 249 \\
\hline & $1^{\prime}$ den fazla & 70 & 2,55 & ,76 & & & \\
\hline \multirow[t]{2}{*}{ Anlamsızlık } & 1 & 230 & 3,00 & 99 &,- 04 & 298 & 971 \\
\hline & 1'den fazla & 70 & 3,01 & 1,00 & & & \\
\hline
\end{tabular}

Tablo 21'e göre öğrencilerin eğitim aldıkları üniversite sayılarına göre genel okula yabancılaşma, güçsüzlük, kuralsızık, soyutlanmışlık ve anlamsızlık düzeyleri anlamlı bir farklılık göstermemiştir (pgenel>,05; pgüçsüzlük $>, 05$; pkuralsızlık>,05; psoyutlanmışlık $>, 05 ;$ panlamsızlık $>, 05)$.

Tablo 22. Yaş Değişkeni ile Öğrenci Yabancılaşma Ölçeği Genel ve Alt Ölçek Puanları Arasındaki ilişkilere Ait Pearson Testi Sonuçları

\begin{tabular}{|c|c|c|c|c|c|}
\hline Değişkenler & $N$ & $\overline{\mathbf{X}}$ & ss & $r$ & $p$ \\
\hline Genel & 300 & 2,77 & ,66 &,- 12 &, $031^{* *}$ \\
\hline Yaş & 300 & 22,6 & 1,70 & & \\
\hline Güçsüzlük & 300 & 2,43 & 79 &,- 16 &, $006^{*}$ \\
\hline Yaş & 300 & 22,6 & 1,70 & & \\
\hline Kuralsızlık & 300 & 3,13 & , 85 &,- 05 & 381 \\
\hline Yaş & 300 & 22,6 & 1,70 & & \\
\hline Soyutlanmışlık & 300 & 2,65 & 87 &,- 07 & 250 \\
\hline Yaş & 300 & 22,6 & 1,70 & & \\
\hline Anlamsızlık & 300 & 3,01 & 99 & -10 & 081 \\
\hline Yaş & 300 & 22,6 & 1,70 & & \\
\hline
\end{tabular}

$*<0,01$ düzeyinde istatistiksel olarak anlamlıdır.

$* *<0,05$ düzeyinde istatistiksel olarak anlamlıdır.

Tablo 22'ye göre öğrencilerin yaşları ile kuralsızlık, soyutlanmışlık ve anlamsızlık düzeyleri arasında anlamlı bir ilişki bulunmamıştır (pkuralsızlık $>, 05$; psoyutlanmışlık $>, 05$; panlamsızlık $>, 05$ ). Öğrencilerin yaşları ile genel okula yabancılaşma ve güçsüzlük düzeyleri arasında negatif yönde anlamlı bir ilişki olduğu görülmektedir (pgenel<,05; rgenel=-,12; pgüçsüzlük<,01; rgüçsüzlük=-,16). Buna göre öğrencilerin yaşları arttıkça genel okula yabancılaşma ve güçsüzlük düzeyleri azalmaktadır.

\section{Sonuç ve Öneriler}

Son sınıftaki okul öncesi öğretmen adaylarının okul tükenmişliği düzeylerine ait sonuçlara göre, son sınıftaki okul öncesi öğretmen adaylarının büyük bir çoğunluğu orta düzeyde okul tükenmişliği yaşamaktadır. Balkıs, Duru, Buluş ve Duru'nun (2011) öğretmen adayları üzerine yaptıkları araştırmada öğrencilerin \%60,4'ünün orta düzeyde tükenmişlik yaşadıkları sonucuna ulaşıımıştır. Tümkaya'nın (2016) son sınıfta öğrenim gören sınıf öğretmeni adayları ile yaptığı araştırma sonucunda öğrencilerin daha çok tükenmişlik tehlikesi içinde olduğu ve tükenmişlik yaşadıkları belirlenmiştir. Benzer şekilde Tümkaya ve Çavuşoğlu'nun (2010) sınıf öğretmenliği bölümü son sınıf öğrencileri ile yaptıkları araştırmada çalışmaya katılan öğrencilerin neredeyse yarısı tükenmişlik yaşama tehlikesi içindedir. Sözü edilen araştırma sonuçları ile yapılan bu araştırma sonucu örtüşmektedir. Bu araştırmanın sonuçlarıyla çelişen bazı 
araştırmalar da mevcuttur. Ören ve Türkoğlu'nun (2006) öğretmen adaylarıyla gerçekleştirdikleri araştırmada Okul Öncesi Öğretmenliği bölümü öğrencilerinin düşük düzeyde tükenmişlik yaşadıkları belirtilmiştir. Çankaya, Başar, Koçoğlu ve Demirkol'un (2012) fen bilgisi, matematik, Türkçe, sosyal bilgiler öğretmeni adayları ile yaptıkları araştırmada öğrencilerin "nadiren" tükenmişlik yaşadıkları sonucuna varılmıştır. Bu farklılığın bir nedeni olarak, değişik üniversitelerdeki sosyal ortam farklılıkları ve öğrenci çalışma koşulları gösterilebilir. Öğrencilerin orta düzeyde yaşadıkları okul tükenmişliği ve okula yabancılaşma problemleri gerekli çözümlerin bulunmaması, konunun önemsenmemesi ve öğrencilere yeterli destek sağlanmaması, önleme çalışmalarının yapılmaması gibi durumlarda yüksek düzeylere ulaşabilir. Bu durum da öğretmen adaylarının mesleki eğitim süreçlerinde kalitenin düşmesine yol açarak mesleğin gerektirdiği yeterliliklere sahip öğretmen yetiştirme hedefine ulaşılmasını engelleyebilir.

Son sınıftaki okul öncesi öğretmen adaylarının üniversite türü değişkenine göre okul tükenmişliği düzeylerine ait sonuçlar, devlet üniversitelerinde öğrenim görmekte olan öğrencilerin özel üniversitelerdeki öğrencilere göre tükenmişliğin bir boyutu olarak daha fazla duyarsızlaştıklarını ve tükendiklerini göstermektedir. Yetkinlik alt boyutunda ise iki grup arasında anlamlı bir farklılık görülmemiştir. İlgili literatür incelendiğinde üniversite türü değişkenine göre üniversite öğrencilerinin okul tükenmişliği düzeylerinin araştırıldığı bir çalışmaya rastlanmamıştır. Böyle bir sonuca ulaşılmasının nedeni olarak özel üniversitelerde eğitim alan öğrencilerin büyük bir çoğunluğunun ücretli öğrenim görmesi ve dolayısıyla memnuniyeti sağlamak amacıyla gerek üniversite yönetimi gerekse akademik personel tarafından öğrencilere daha hoşgörülü bir yaklaşımın benimsenmesi gösterilebilir. Devlet üniversitelerindeki öğrencilerin okulla veya derslerle ilgili sıkıntıları göz ardı ediliyor olabilir. Dolayısıyla devlet üniversitelerinde eğitim alan öğrenciler daha fazla duyarsızlaşma ve okul tükenmişliği yaşıyor olabilirler.

Son sınıftaki okul öncesi öğretmen adaylarının mezun olunan lise türü değişkenine göre okul tükenmişliği düzeylerine ait sonuçlar, Anadolu öğretmen lisesi mezunlarının genel lise mezunu ve meslek lisesi mezunu olanlara göre daha fazla tükenmiş olduklarını göstermiştir. Buna ek olarak okul tükenmişliğinin duyarsızlaşma ve yetkinlik alt boyutlarında lise türüne göre bir farklılık bulunmamış iken; tükenme alt boyutunda yine Anadolu öğretmen lisesi mezunlarının meslek lisesi mezunlarına göre daha fazla tükendikleri sonucuna ulaşılmıştır. Şimşek-Bekir, Şahin ve Şanlı’nın (2012) araştırmasına göre öğrencilerin tükenmişlik düzeyleri mezun oldukları lise türüne göre farklılık göstermemiştir. Sözü edilen araştırma incelendiğinde çalışma grubundaki öğrencilerin "Anadolu lisesi, genel lise, meslek lisesi ve teknik lise" mezunu oldukları görülmektedir. Araştırmamızın sonuçları ile örtüşmeyen bu durumun bir nedeni, söz konusu araştırmada çalışma grubunda Anadolu öğretmen lisesi mezunu öğrencilerin bulunmaması olabilir. Araştırma sonucunu destekleyen Çapulcuoğlu ve Gündüz'ün (2013) bir çalışmasında en yüksek düzeyde tükenmişlik yaşayan grupların Anadolu öğretmen lisesi, Anadolu lisesi ve fen lisesi mezunları oldukları sonucuna varılmıştır. Bunun bir olası nedeni olarak, meslek liselerine göre Anadolu liselerinde ve Anadolu öğretmen liselerinde verilen eğitimin daha kapsamlı ve yüklü olması gösterilebilir.

Okul öncesi öğretmen adaylarının eğitim alınan üniversite sayısı değişkenine göre okul tükenmişliği düzeylerine ait sonuçlara bakıldığında, öğrencilerin okul tükenmişliği, tükenme ve duyarsızlaşma alt boyut düzeylerinde ilgili değişkene göre farklılık olmadığı görülmüştür. İlgili alan yazında öğrencilerin eğitim aldıkları üniversite sayısına göre okul tükenmişliği düzeylerinin incelendiği herhangi bir araştırmaya rastlanmamıştır.

Okul öncesi öğretmen adaylarının yaşları ile okul tükenmişliği düzeyleri arasındaki ilişkiye ait sonuçlar; okul tükenmişliği, tükenme ve duyarsızlaşma alt boyut düzeyleri ile yaş arasında istatistiksel olarak anlamlı bir ilişki olmadığını göstermiştir. Güdük, vd.'nin (2005) tıp fakültesi son sınıf öğrencileri ile yaptıkları araştırmada öğrencilerin tükenmişlik düzeylerinin yaşlarına göre anlamlı bir farklılık göstermediği belirlenmiştir. Bu sonuç ile araştırma sonuçları örtüşmektedir. Şimşek-Bekir, Şahin ve Şanlı'nın (2012) araştırmasında "23-24" yaşındaki öğrencilerin tükenmişlik düzeylerinin "19-20" yaşındakilere göre daha yüksek olduğu bulunmuştur. Bulunan sonuç, yapılan bu araştırma ile çelişmektedir. Bu durum, araştırmamızın örneklem grubunun son sınıf öğrencilerden oluşmasından dolayı öğrencilerin yaşlarının genel olarak birbirine yakın olmasından kaynaklanmış olabilir.

Araştırmamızda son sınıftaki okul öncesi öğretmen adaylarının okula yabancılaşma düzeylerine ait sonuçlara göre son sınıftaki okul öncesi öğretmen adaylarının okula yabancılaşma düzeyleri orta ve düşük düzeydedir. Coşkun ve Altay (2009); Çağlar (2013); Aydın ve Akar, 2014; Şimşek ve Ataş-Akdemir (2015); Ayık, Uzun, Ataş ve Yücel (2015); Polat, Dilekmen ve Yasul (2015); Çelik ve Babaoğlan'ın (2017) üniversite öğrencileri ile yaptıkları araştırmalarda öğrencilerin yabancılaşma düzeylerinin orta düzeyde olduğu sonucuna ulaşılmıştır. Tüm bu araştırma sonuçları, araştırmamızın bulgularını orta düzey yabancılaşma bakımından destekler niteliktedir. Böyle bir sonuca ulaşılmasının nedenleri arasında, eğitim sisteminde sık sık yapılan değişimlerin ve üniversitelerde benimsenen yanlış eğitim politikalarının 
öğrenciler üzerinde oluşturduğu olumsuz etkiler gösterilebilir. Araştırma sonuçlarının birbirleriyle benzer olması, öğrencilerde görülen okula yabancılaşmanın oldukça önemli düzeyde olduğunu göstermektedir.

Son sınıftaki okul öncesi öğretmen adaylarının üniversite türü değişkenine göre okula yabancılaşma düzeylerine ait sonuçlar, devlet üniversitelerinde ve özel üniversitelerde eğitim alan öğrencilerin okula yabancılaşma, güçsüzlük, kuralsızlık, soyutlanmışık alt boyutları arasında anlamlı bir farklılı̆ın bulunmadığını göstermektedir. Buna ek olarak devlet üniversitelerindeki öğrencilerin anlamsızlık alt boyutu özeldekilere göre daha yüksek düzeydedir. Kır, Altay ve Ceyhan'ın (2014) lise öğrencilerinin yabancılaşma düzeylerini inceledikleri araştırma sonucunda mezun olunan ilköğretim okulu değişkeninde özel okulda ve devlet okulunda öğrenim görmüş olan öğrenciler arasında anlamlı bir farklılık bulunmamıştır. Bu araştırma sonucu her ne kadar lise öğrencileri ile ilgili olsa da söz konusu sonuç, araştırmamızın sonucuyla benzerlik göstermektedir.

Son sınıftaki okul öncesi öğretmen adaylarının mezun olunan lise türü değişkenine göre okula yabancılaşma düzeylerine ait sonuçlar, Anadolu lisesi mezunu olan öğrencilerin genel lise mezunlarına göre daha fazla okula yabancılaşma yaşadıklarını göstermiştir. Kır, Altay ve Ceyhan'ın (2014) lise öğrencileri ile gerçekleştirdikleri araştırmanın sonuçları, Anadolu lisesinde öğrenim görmekte olan öğrencilerin genel lisedeki öğrencilere göre daha yüksek düzeyde yabancılaşma yaşadıklarını göstermektedir. Gedik'in (2014) lise öğrencilerinin yabancılaşma düzeyini incelediği araştırmada, Anadolu lisesi öğrencilerinin meslek lisesi ve genel lise öğrencilerine göre daha fazla yabancılaşma yaşadıkları sonucu ortaya çıkmıştır. Sözü edilen araştırmalardan elde edilen bu sonuçlar, araştırma sonucunu destekler niteliktedir. Bu araştırmada elde edilen bir diğer sonuca göre okula yabancılaşmanın alt boyutlarından olan güçsüzlük, kuralsızlık ve soyutlanmışlık düzeyleri son sınıftaki okul öncesi öğretmen adaylarının mezun oldukları lise türü değişkenine göre farklılık göstermemektedir. Anlamsızlık alt boyutu ele alındığında ise Anadolu öğretmen lisesi ve Anadolu lisesi mezunlarının anlamsızlık düzeyleri genel lise mezunlarına göre daha yüksektir. Bu araştırma sonuçlarını yukarıda sözü edilen Kır, Altay ve Ceyhan (2014) ile Gedik'in (2014) yaptıkları araştırma sonuçları destekler niteliktedir. Bu durumun Anadolu lisesi eğitimi programının öğrencilere çok yüklü gelmesi ile ilgili olduğu düşünülebilir.

Okul öncesi öğretmen adaylarının eğitim alınan üniversite sayısı değişkenine göre okula yabancılaşma düzeylerine ait sonuçlara bakıldığında, öğrencilerin okula yabancılaşma, güçsüzlük, kuralsızlık, soyutlanmışlık ve anlamsızlık alt boyut düzeylerinde ilgili değişkene göre farkılık olmadığı görülmüştür. İlgili alan yazında öğrencilerin eğitim aldıkları üniversite sayısına göre okula yabancılaşma düzeylerinin incelendiği herhangi bir araştırmaya rastlanmamıştır.

Okul öncesi öğretmen adaylarının okul tükenmişliği ve okula yabancılaşma düzeylerinin eğitim aldıkları üniversite sayısına göre farklılık göstermemesi sonucu, beklenmeyen bir sonuçtur çünkü; araştırmacı tarafından birden fazla üniversitede eğitim alan öğrencilerin eğitim-öğretim hayatları uzadığından dolayı daha yüksek düzeyde tükenme ve yabancılaşma yaşayabilecekleri düşünülmüştür. Bu sonuca ulaşılmasına neden olan etmen ise okul öncesi eğitimi bölümünün mezun olduktan sonra iş bulma açısından öğrencilere zorluk çıkarmayacak bir bölüm olması olabilir. Okul öncesi eğitimi bölümüne ikinci veya üçüncü üniversite olarak eğitim almaya gelen öğrenciler genel olarak ilk mezun oldukları bölümlerden iş bulamayan öğrencilerdir. Dolayısıyla bu bölümde iş bulabilme ümidiyle ve hevesiyle eğitimlerini sürdürme ihtimalleri yüksektir. Bundan dolayı okul tükenmişliği ve okula yabancılaşma düzeyleri ilk üniversitesinde eğitim alan öğrencilere göre farklılık göstermemiş olabilir.

Son sınıftaki okul öncesi öğretmen adaylarının yaşları ile okula yabancılaşma düzeylerine ilişkin sonuçlarda, kuralsızık, soyutlanmışık ve anlamsızık alt boyut düzeyleri ile yaş arasında anlamlı bir ilişki olmadığı görülmektedir. Bu sonuca ek olarak öğrencilerin okula yabancılaşma ve güçsüzlük alt boyut düzeyleri ile yaşları arasında negatif yönlü ilişki olduğu belirlenmiştir. Öğrencilerin yaşları artııça okula yabancılaşma ve güçsüzlük alt boyut düzeyleri azalmaktadır. Çelik ve Babaoğlan'ın (2017) araştırmasına göre üniversite öğrencilerinin yaşlarına göre güçsüzlük, kuralsızlık, soyutlanmışık ve anlamsızlık düzeyleri farklıık göstermemektedir. Bu sonuç, güçsüzlük alt boyutu dışında araştırma sonuçlarıyla benzerlik göstermektedir. Kilchenstein'in (2008) araştırmasına göre ise, öğrencilerin yaşları arttıkça yabancılaşma düzeyleri de artmaktadır. Sözü edilen araştırma sonucu, bu araştırma sonuçlarıyla örtüşmemektedir. Bu farklılığın nedeni araştırmaların gerçekleştirildiği kültürlerin ve bu kültürlere ait eğitim sistemlerinin birbirinden farklı olması olabilir.

Okul öncesi öğretmen adaylarının okul tükenmişliği ve okula yabancılaşma düzeyleri ile yaş değişkeni arasındaki ilişkiye ait sonuçlar ele alındığında, araştırmaya katılan öğrencilerin yaşları ile tükenme, duyarsızlaşma, kuralsızlık, soyutlanmışlık ve anlamsızlık alt boyutları arasında anlamlı bir ilişkinin bulunmamasının nedeni olarak son sınıf öğrencileri ile çalışıldığı için yaşların birbirine yakın olması durumu düşünülebilir. Yaşı büyük olan öğrencilerin diğerlerine göre daha düşük düzeyde okula yabancılaşma ve güçsüzlük durumları yaşamaları ise yaş ile beraber 
bireylerin problemlerle mücadele edebilme yeteneğinin gelişmesi olarak açıklanabilir. Deneyim yetersizliğinden dolayı küçük yaştaki öğrenciler kriz durumları ile nasıl başa çıkacaklarını bilemeyebilirler, bu durum zaman içinde tecrübe kazandıkça tersine dönebilir.

- Bu araştırma yalnızca kız öğrencilerden alınan veriler ile sınırlıdır. Bu nedenle sonraki araştırmalarda erkek öğrencilerin de çalışma grubuna dahil edildiği daha geniş gruplarla araştırmalar yapılması önerilebilir.

- Araştırmaya katılan öğrencilerin büyük bir çoğunluğu orta sosyoekonomik düzeye ait olduklarını bildirdiklerinden dolayı sosyoekonomik düzey değişkenine göre veri analizi yapılamamıştır. Sonraki araştırmalarda alt ve üst sosyoekonomik düzeydeki öğrencilerin de yabancılaşma ve tükenmişlik düzeylerinin incelenmesi, sosyoekonomik düzey değişkenine göre analizler yapılması önerilebilir.

- Öğretim üyelerine/elemanlarına ders verdikleri öğrenci gruplarında öğrencileriyle aralarında açık iletişimin bulunmasına özen göstermeleri, eğlenceli bir öğrenme ortamı oluşturmaları, öğrencinin ilgisini derse çekebilmeleri konusunda önerilerde bulunulabilir.

- Orta düzeyde tükenme ve yabancılaşma yaşayan öğrencilere okul dışı sosyal faaliyetlere de önem vermeleri, kendilerini sadece derslerle, ödevlerle, projelerle, okulla ve okula yönelik diğer etkinliklerle sınırlandırmamaları önerilebilir.

\section{Kaynakça}

Aydın, S. ve Akar, H. (2014). Öğretmen adaylarının yabancılaşma düzeylerine fakülte yaşam niteliğinin etkisinin incelenmesi. Eğitim ve Öğretim Araştırmaları Dergisi, 4 (2), 161-172.

Ayık, A., Uzun, T., Ataş, Ö. ve Yücel, E. (2015). Öğrencilerin genel sinizm tutumları ve okula yabancılaşma algıları arasındaki ilişkilerin incelenmesi. The Journal of Academic Social Science Studies, 39, 491-508.

Aypay, Y. ve Eryılmaz, A. (2011). Lise öğrencilerinin derse katılmaya motive olmaları ile okul tükenmişliği arasındaki ilişkinin incelenmesi. Mehmet Akif Ersoy Üniversitesi Eğitim Fakültesi Dergisi, 21, 26-44.

Balkıs, M., Duru, E., Buluş, M. ve Duru, S. (2011). Tükenmişliğin öğretmen adayları arasındaki yaygınlığı, demografik değişkenler ve akademik başarı ile ilişkisi. Pamukkale Üniversitesi Eğitim Fakültesi Dergisi, 229, 151-165.

Bresó, E., Salanova, M. \& Schaufeli, W.B. (2007). In search of the 'Third Dimension' of burnout: Efficacy or inefficacy? Applied Psychology: An International Review, 56, 3, 460-478.

Coşkun, Y. ve Altay, C.A. (2009). Lise öğrencilerinde yabancılaşma ve benlik algısı ilişkisi. M.Ü. Atatürk Eğitim Fakültesi Eğitim Bilimleri Dergisi, 29, 41-56.

Cushman, S. \& West, R. (2006). Precursors to college student burnout: Developing a typology of understanding. Qualitative Research Reports in Communication, 7, 23-31.

Çağlar, Ç. (2012). Öğrenci Yabancılaşma Ölçeği'nin (ÖYÖ) geliştirilmesi. Eğitim ve Bilim, 37, 166, 195-205.

Çağlar, Ç. (2013). Eğitim fakültesi öğrencilerinin yabancılaşma düzeyleri ile öğretmenlik mesleğine yönelik tutumları arasındaki ilişki. Kuram ve Uygulamada Eğitim Bilimleri, (13) 3, 1497-1513.

Çankaya, İ., Başar, M., Koçoğlu, E. ve Demirkol, A. (2012). Meslek öncesi dönemde tükenmişliğe ilişkin öğretmen adaylarının görüşleri. Turkish Studies - International Periodical For The Languages, Literature and History of Turkish or Turkic, 7 (3), 751 758.

Çapri, B., Gündüz, B. ve Gökçakan, Z. (2011). Maslach tükenmişlik envanteri-öğrenci formu (mte-öf)'nun türkçe'ye uyarlaması: geçerlik ve güvenirlik çalışması, Çukurova Üniversitesi Eğitim Fakültesi Dergisi. 40 (1), 134-147.

Çapulcuoğlu, U. ve Gündüz, B. (2013). Lise öğrencilerinde tükenmişliğin cinsiyet, sınıf düzeyi, okul türü ve algılanan akademik başarı değişkenlerine göre incelenmesi. Trakya Üniversitesi Eğitim Fakültesi Dergisi, 3, 1, 12-24.

Çavuşoğlu, ì. (2009). Sınıf öğretmenliği son sınıf öğretmen adaylarının tükenmişlik düzeylerinin incelenmesi. Yayımlanmamış yüksek lisans tezi. Çukurova Üniversitesi Sosyal Bilimler Enstitüsü, Adana.

Çelik, E. ve Babaoğlan, E. (2017). Üniversite öğrencilerinin yabancılaşma düzeyi. Ahi Evran Üniversitesi Kırşehir Eğitim Fakültesi Dergisi, 18 (1), 405-427.

Çivitci, N. (2011). School Alienation and Perceived Social Support as Predictors of School Anger in High School Students. Elementary Education Online, 10 (3), 861-871.

Durán, A., Extremera, N., Rey, L., Fernández-Berrocal, P. \& Montalbán, F.M. (2006). Predicting academic burnout and engagement in educational settings: Assessing the incremental validity of perceived emotional intelligence beyond perceived stress and general self-efficacy. Psicothema, 18, 158-164.

Duru, E. (1995). Üniversite öğrencilerinde yabancılaşma ve yalnızlık düzeyi ilişkisi. Yayımlanmamış yüksek lisans tezi. Dokuz Eylül Üniversitesi, Sosyal Bilimler Enstitüsü, İzmir. 
Dyrbye, L.N., Thomas, M.R., Huntington, J.L., Lawson, K.L., Novotny, P.J., Sloan, J.A. \& Shanafelt, T.D. (2006). Personal life events and medical student burnout: a multicenter study. Academic Medicine, 81 (4), 374-384.

Erjem, Y. (2005). Eğitimde yabancılaşma olgusu ve öğretmen: Lise öğretmenleri üzerine sosyolojik bir araştırma. Türk Eğitim Bilimleri Dergisi, (3) 4, 395-415.

Erturgut, R. ve Soyşekerci, S. (2010). An empirical analysis on burnout levels among second year vocational schools students. Procedia Social and Behavioral Sciences, 2, 1399-1404.

Gedik, A. (2014). Ortaöğretim öğrencilerinde okul yaşam kalitesi bağlamında okula yabancılaşma. Yayımlanmamış Yüksek Lisans Tezi. İnönü Üniversitesi, Eğitim Bilimleri Enstitüsü, Malatya.

Güdük, M., Erol, Ş., Yağcıbulut, Ö., Uğur, Z., Özvarış, Ş.B. ve Aslan, D. (2005). Ankara'da Bir Tıp Fakültesi'nde Okuyan Son Sınıf Öğrencilerde Tükenmişlik Sendromu. Sürekli Tıp Eğitimi Dergisi, 14 (8), 169-173.

Jacobs, S.R. \& Dodd, D.K. (2003). Student burnout as a function of personality, social support, and workload. Journal of College Student Development, 44, 291-303.

Katıtaş, S. (2012). ilköğretim ikinci kademe öğrencilerinde okula yabancılaşma ve okulu bırakma eğilimi (Şanlıurfa ili örneği). Yayımlanmamış yüksek lisans tezi. Harran Üniversitesi, Sosyal Bilimler Enstitüsü, Şanlıurfa.

Kır, İ., Altay, C.A. ve Ceyhan, E. (2014). Lise 9. sınıf öğrencilerinin yabancılaşma düzeylerinin ve şiddete yönelik tutumlarının bazı değişkenler açısından incelenmesi. KSÜ Sosyal Bilimler Dergisi, 11 (1), 155-174.

Kilchenstein, D.B. (2008). Organizational alienation and minortiy students. Unpublished master thesis, Duquesne University, Pittsburgh.

Marshall, G. (1999). Sosyoloji sözlüğü. Ankara: Bilim ve Sanat.

Maslach, C. \& Jackson, S.E. (1981). The measurement of experienced burnout. Journal of Occupational Behaviour, (2), 99-113.

Okutan, E. (2010). Kişilik özelliklerinin tükenmişliğe etkisi: bir örnek olay incelemesi. Yayımlanmamış doktora tezi, Sakarya Üniversitesi Sosyal Bilimler Enstitüsü, Sakarya.

Ören, N. ve Türkoğlu, H. (2006). Öğretmen adaylarında tükenmişlik. Muğla Üniversitesi Sosyal Bilimler Enstitüsü Dergisi, 16.

Özçınar, M. (2011). Örgütlerde yabancılaşma ile tükenmişlik sendromu arasındaki ilişkiyi belirlemeye yönelik bir araştırma. Yayımlanmamış yüksek lisans tezi, Dumlupınar Üniversitesi, Sosyal Bilimler Enstitüsü, Kütahya.

Parsıl, A.M. (2007). Sınıf örgütünde yabancılaşma. Yayımlanmamış yüksek lisans tezi, Cumhuriyet Üniversitesi, Sosyal Bilimler Enstitüsü, Sivas.

Polat, M., Dilekmen, M. ve Yasul, A.F. (2015). Öğretmen adaylarındaokula yabancılaşma ve akademik öz-yeterlik: bir Chaid Analizi incelemesi. Uluslararası Eğitim Bilimleri Dergisi, 2, 4, 214-232.

Repetowski, W. (1989). Expectation of unemployment and student alienation. (Master Thesis dissertation, The University of Alberta). National Library of Canada.

Schaufeli, W.B., Martinez, I., Marques-Pinto, A., Salanova, M. \& Bakker, A. (2002). Burnout and engagement in university students: A cross-national study. Journal of Cross Cultural Studies, 33, 464-481.

Şimşek, H. ve Ataş-Akdemir, Ö. (2015). Üniversite öğrencilerinde okula yabancılaşma. Current Research in Education, 1 (1), 1-12.

Şimşek-Bekir, H., Şahin, H. ve Şanlı, H. S. (2012). Eğitim Fakültesi'nde öğrenim gören öğrencilerin tükenmişlik düzeylerinin bazı değişkenlere göre incelenmesi. e-Journal of New World Sciences Academy, 7 (2), 18-32.

Tarquin, K. \& Cook-Cottone, C. (2008). Relationships among aspects of student alienation and self concept. School Psychology Quarterly, 23 (1), 16-25.

Tezcan, M. (1997). Gençlik sosyolojisi ve antropolojisi araştırmaları. Ankara: Ankara Üniversitesi Eğitim Bilimleri Fakültesi Yayınları.

Trusty, J. \& Dooley-Dickey, K. (1993). Alienation from school: An exploratory analysis of elementary and middle school students preceptions. Journal of Research and Development in Education, (26) 4, 232-242.

Tümkaya, S. (2016). Sınıf öğretmenliği öğrencilerinin tükenmişlik ve yabancılaşma düzeylerinin incelenmesi. Ç.Ü. Sosyal Bilimler Enstitüsü Dergisi, 25, 2, 251-268.

Tümkaya, S. ve Çavuşoğlu, í. (2010). Sınıf Öğretmenliği son sınıf öğretmen adaylarının tükenmişlik düzeylerinin incelenmesi. Ç.Ü. Sosyal Bilimler Enstitüsü Dergisi, 19 (2), 468-481.

Warner, B.S., Weist, M.D. \& Krulak, A. (1999). Risk factors for school violence. Urban Education, (34) 1, 52-68.

Weckwerth, A.C. \& Flynn, D.M. (2006). Effect of sex on perceived support and burnout in university students.

College Student Journal, 40, 237-250. 